February 2005 - NREL/CP-520-37477

\title{
A Comprehensive Model of Hydrogen Transport into a Solar Cell During Silicon Nitride Processing for Fire-Through Metallization
}

B. Sopori, R. Reedy, K. Jones, Y. Yan, and M. Al-Jassim

National Renewable Energy Laboratory

Y. Zhang

Bioarray Solutions

B. Bathey and J. Kalejs RWE Schott Solar

Prepared for the $31^{\text {st }}$ IEEE Photovoltaics Specialists Conference and Exhibition

Lake Buena Vista, Florida January 3-7, 2005
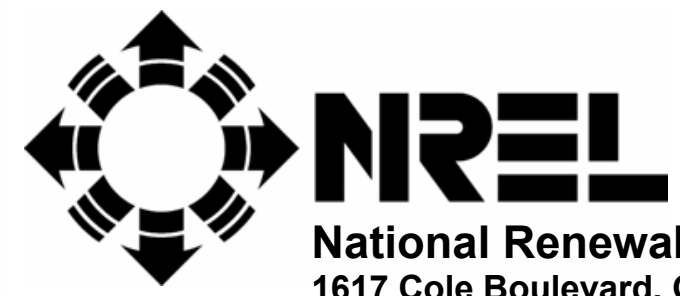

National Renewable Energy Laboratory 1617 Cole Boulevard, Golden, Colorado 80401-3393 303-275-3000 • www.nrel.gov

Operated for the U.S. Department of Energy Office of Energy Efficiency and Renewable Energy by Midwest Research Institute $\bullet$ Battelle 


\section{NOTICE}

The submitted manuscript has been offered by an employee of the Midwest Research Institute (MRI), a contractor of the US Government under Contract No. DE-AC36-99G010337. Accordingly, the US Government and MRI retain a nonexclusive royalty-free license to publish or reproduce the published form of this contribution, or allow others to do so, for US Government purposes.

This report was prepared as an account of work sponsored by an agency of the United States government. Neither the United States government nor any agency thereof, nor any of their employees, makes any warranty, express or implied, or assumes any legal liability or responsibility for the accuracy, completeness, or usefulness of any information, apparatus, product, or process disclosed, or represents that its use would not infringe privately owned rights. Reference herein to any specific commercial product, process, or service by trade name, trademark, manufacturer, or otherwise does not necessarily constitute or imply its endorsement, recommendation, or favoring by the United States government or any agency thereof. The views and opinions of authors expressed herein do not necessarily state or reflect those of the United States government or any agency thereof.

Available electronically at http://www.osti.gov/bridge

Available for a processing fee to U.S. Department of Energy and its contractors, in paper, from:

U.S. Department of Energy

Office of Scientific and Technical Information

P.O. Box 62

Oak Ridge, TN 37831-0062

phone: 865.576 .8401

fax: 865.576.5728

email: mailto:reports@adonis.osti.gov

Available for sale to the public, in paper, from:

U.S. Department of Commerce

National Technical Information Service

5285 Port Royal Road

Springfield, VA 22161

phone: 800.553 .6847

fax: 703.605.6900

email: orders@ntis.fedworld.gov

online ordering: http://www.ntis.gov/ordering.htm 


\title{
A COMPREHENSIVE MODEL OF HYDROGEN TRANSPORT INTO A SOLAR CELL DURING SILICON NITRIDE PROCESSING FOR FIRE-THROUGH METALLIZATION
}

\author{
Bhushan Sopori ${ }^{1}$, Yi Zhang ${ }^{2}$, Robert Reedy ${ }^{1}$, Kim Jones $^{1}$, Yanfa Yan ${ }^{1}$, Mowafak Al-Jassim¹, \\ Bala Bathey ${ }^{3}$, and Juris Kalejs ${ }^{3}$ \\ ${ }^{1}$ National Renewable Energy Laboratory, 1617 Cole Blvd., Golden, CO 80401 \\ 2 Bioarray Solutions, Warren, NJ 07059 \\ 3 RWE Schott Solar, Billerica, MA 01821
}

\section{ABSTRACT}

A mechanism for the transport of $\mathrm{H}$ into a Si solar cell during plasma-enhanced chemical vapor deposition (PECVD) of a hydrogenated silicon nitride ( $\mathrm{SiN}: \mathrm{H})$ layer and its subsequent fire-through metallization process is described. The PECVD process generates processinduced traps, which "store" $\mathrm{H}$ at the surface of the solar cell. This stored $\mathrm{H}$ is released and diffuses rapidly into the bulk of Si during the high-temperature metallization-firing process. During the ramp-down, the diffused $\mathrm{H}$ associates with impurities and defects and passivates them. The firing step partially heals up the surface damage. The proposed model explains a variety of observations and experimental results.

\section{INTRODUCTION}

In the current technology for commercial $\mathrm{Si}$ solar cell fabrication, hydrogen passivation is a byproduct of two other process steps-deposition of antireflection coating and subsequent contact-metallization firing. In this "firethrough" process, a layer of hydrogenated silicon nitride (SiN:H) is deposited on an N/P junction by a PECVD technique $[1,2]$. Next, the front metallization pattern is screen-printed and fired through the nitride layer. In some cases, a back contact is also screen-printed prior to the firing step, and both contacts are co-fired. It has been determined that the firing process is accompanied by a large increase in the minority carrier lifetime of the cell, indicating that passivation of impurities and defects in the bulk occurs primarily during this step. Fourier transform infrared (FTIR) spectroscopic studies have shown that the firing step is also accompanied by a release of $\mathrm{H}$ from $\mathrm{SiN}: \mathrm{H}$ layer. These two factors have prompted suggestions that the $\mathrm{H}$ for passivation of impurities and defects in the bulk of the solar cell comes from SiN:H layer and diffuses into $\mathrm{Si}$. Thus, the $\mathrm{H}$ transport occurs primarily from plasma to $\mathrm{SiN}: \mathrm{H}$ film and then to $\mathrm{Si}[3]$.

Some researchers have argued that $\mathrm{H}$ released from $\mathrm{SiN}: \mathrm{H}$ cannot be the source of passivating $\mathrm{H}$, because it is more favorable for $\mathrm{H}$ to evolve into air than make its way into the Si substrate [4]. These arguments are based on kinetic studies of $\mathrm{H}$-evolution from $\mathrm{SiN}: \mathrm{H}$, and from theoretical modeling of chemical reactions in $\mathrm{SiN}: \mathrm{H}$ during high-temperature processing. From these arguments, it was thought that the SiN:H fire-through process cannot be an efficient passivation scheme [5]. However, based on theoretical modeling of trapping-assisted $\mathrm{H}$ diffusion in $\mathrm{Si}$, we have proposed a different hypothesis to explain efficient passivation by $\mathrm{SiN}: \mathrm{H}$ processing [6,7]. It was predicted that $\mathrm{H}$ is introduced into $\mathrm{Si}$ during $\mathrm{SiN}: \mathrm{H}$ deposition itself. This introduction is facilitated by the process-induced defects (see discussion below), which are generated primarily during the initial phase of the nitride deposition or during a "pretreatment," in which the cell is exposed to a plasma without Si-bearing gases.

In this paper, we explore the nature of processinduced traps (PITs), and address how these PITs mediate $\mathrm{H}$ diffusion into $\mathrm{Si}$. We show that PITs are manifested as a damaged surface layer, which contains very high concentrations of $\mathrm{H}$. The surface damage can be observed by TEM and the SIMS profiles of $\mathrm{H}$ (near the surface). A host of other analytical techniques is used to understand association and detrapping of $\mathrm{H}$ from the PITs. We also show that $\mathrm{H}$ is released from PITs and a part of the damage is healed as a result of firing. Furthermore, some of the PITs can transform into other extended defects through the firing process.

\section{PROCESS-INDUCED TRAPS AND THE DIFFUSION MECHANISM}

It is now well established that traps play a dominant role in controlling the effective solubility and the diffusivity of $\mathrm{H}$ in Si containing defects and impurities [8,9]. Early studies on $\mathrm{H}$ diffusion show that the solubility of $\mathrm{H}$ in relatively pure $\mathrm{Si}$ is very low [10]. However, in impure $\mathrm{Si}$, $\mathrm{H}$ has propensity to associate with impurities and defects, thereby increasing the effective solubility and reducing the diffusivity of $\mathrm{H}$ in $\mathrm{Si}$ [11]. In most cases, the primary traps of $\mathrm{H}$ in $\mathrm{Si}$ are the grown-in defects and impurities. However, we have proposed that a very effective trapping of $\mathrm{H}$ can be done by the process-induced defects. In a passivation process, process-induced defects are typically manifested as the surface damage produced by the hydrogenation process itself (in this case by the plasma) $[12,13]$. Detailed studies have been done on the defects produced by plasma processing for a variety of cases such as low temperature $\left(<400{ }^{\circ} \mathrm{C}\right)$ hydrogenation, ion etching, and plasma-immersion doping. For example, a long duration, low-temperature, plasma hydrogenation (used in the past for impurity/defect passivation) results in extensive surface damage in the form of extended defects 
such as dislocation tangles, stacking faults, and platelets. This damage has a high solubility for $\mathrm{H}$, and leads to formation of a H-rich layer at the surface. Because in a typical $\mathrm{SiN}: \mathrm{H}$ deposition (for antireflection coating) it is expected that the Si surface is exposed to the plasma for only a very brief period, it is often believed that there is little or no damage at the wafer or cell surface. Indeed, it is difficult to observe such damage by standard procedures. Concomitantly detailed information on the effects of short exposures to low-energy plasma processing is severely lacking. However, it is noteworthy that a nitride process, which is optimized for good passivation of solar cells, requires a pretreatment wherein the wafer encounters hydrogen plasma prior to initiation of a nitride deposition. Typically, this is accomplished by blocking the flow of Si-bearing gases during the initial phase of deposition.

During the high-temperature $\left(\sim 800{ }^{\circ} \mathrm{C}\right)$ metallization firing, $\mathrm{H}$ is detrapped from the damage and diffuses into the Si. At these temperatures, the detrapped $\mathrm{H}$ can diffuse with nearly interstitial diffusivity. The hydrogen diffusion can be further improved in those situations where impurity gettering can occur during firing process because gettering is accompanied by a reduction in the bulk trap density. However, annihilation of PITs is more difficult during short temperature pulses (at temperatures of about $800{ }^{\circ} \mathrm{C}$ ). This behavior allows PITs to mediate $\mathrm{H}$ flow across the $\mathrm{SiN}: \mathrm{H} / \mathrm{Si}$ interface during firing.

It is important to point out that impurities near the surface, introduced by other processes, can also influence $\mathrm{H}$ diffusion because they can also act as traps (with temperature dependencies of trapping and detrapping rates different from those of bulk traps). Of particular interest in solar cell fabrication is the trapping in the heavily doped n-type junction.

\section{THEORETICAL MODELING}

We have extended our previous $\mathrm{H}$ rapping/detrapping model to include contribution by the process-induced traps [13]. The surface trap density ( $T$ ) for a plasma process can be represented by the following function:

$$
\left[\mathrm{T}_{\text {tot }}\right]=\mathrm{T}_{0} \exp \left[-\frac{\mathrm{x}}{\mathrm{a}+\mathrm{bt}}\right]+\mathrm{T}_{\mathrm{b}}
$$

where the first time-dependent term is due to process damage and $T_{b}$ is a constant bulk trap density. The basic equations and some results of this model have been published earlier. Here, we simply mention some of the salient results of our theory.

1. A high concentration of $\mathrm{H}$ is "stored" near the surface by a PECVD process (which typically takes a few minutes for the deposition of about $750 \AA$ of nitride) in a profile that corresponds to the $T_{\text {tot }}$ profile.
2. For a good quality material $\left(\mathrm{Tb}<10^{16} \mathrm{~cm}^{-3}\right), \mathrm{H}$ diffuses through the entire bulk in only a few seconds at the firing temperatures.

3. The residual surface concentration of $\mathrm{H}$, after firing, corresponds to the residual trap density. If the surface damage is fully healed, the $\mathrm{H}$ concentration will reach the bulk trap density, typically, $10^{16}-10^{17} \mathrm{~cm}^{-3}$. As pointed out in this paper, a high residual concentration is associated with a poor firing process and /or formation of platelets and stacking faults. The healing of damage is important to achieve a low surface recombination velocity of the solar cell.

4. Because surface damage, produced by different PECVD methods (e.g., remote plasma, high frequency/low frequency plasma) can be different, the performance of solar cells with nitride layers deposited by these techniques may vary. In principle, it should be possible to adjust process conditions to minimize variations due to different methods. However, in practice, it may be difficult to achieve the same cell performance with different PECVD methods, because $H$ passivation and contact formation occur in the same step.

\section{EXPERIMENTAL VERIFICATION}

Experiments were done on $\mathrm{Si}$ wafers and cells using commercial SIN:H process and firing procedures. Although observation of surface damage and trapping/detrapping of $\mathrm{H}$ by the PITs can be facilitated by performing plasma processing for extended periods and substituting deuterium for $\mathrm{H}$, it is important to use the standard process conditions to satisfactorily verify the proposed model.

Here, we show experimental evidence of the proposed mechanism. We first verify that indeed (i) a surface damage is produced during the PECVD nitridation, (ii) $\mathrm{H}$ is trapped near the surface below the nitride layer, and (iii) and $\mathrm{H}$ diffuses into the bulk during firing.

Trapping of hydrogen by the defects produced by ion implantation and plasma processes used for bulk passivation of solar cells have been well documented. Thus, it is not surprising that one would expect surface damage to play an important role in the hydrogenation process. However, the PECVD process for deposition of $\mathrm{SiN}: \mathrm{H}$ is considerably more challenging because the bare surface of $\mathrm{Si}$ is exposed to plasma for a very short duration (only in the initial phase of the PECVD process). Because the surface damage produced by low-energy plasma is very mild, it is difficult to characterize it. Through a variety of characterization techniques and using different substrate materials, we have identified the nature of the damage produced by PECVD-SiN:H deposition for AR coatings. Figure 1 is a cross-sectional TEM image of an EFG ribbon, deposited with a $\mathrm{SiN}: \mathrm{H}$ antireflection coating by PECVD, prior to the firing step. This image shows an unexpected feature: clusters of point defects are introduced near the Si surface. It may be pointed out that 
other hydrogenation processes, such as plasma processing and ion implantation, typically introduce very strong (and easily identifiable) defects such as platelets, stacking faults and hydrogen "bubbles" that segregate at dislocation nodes.

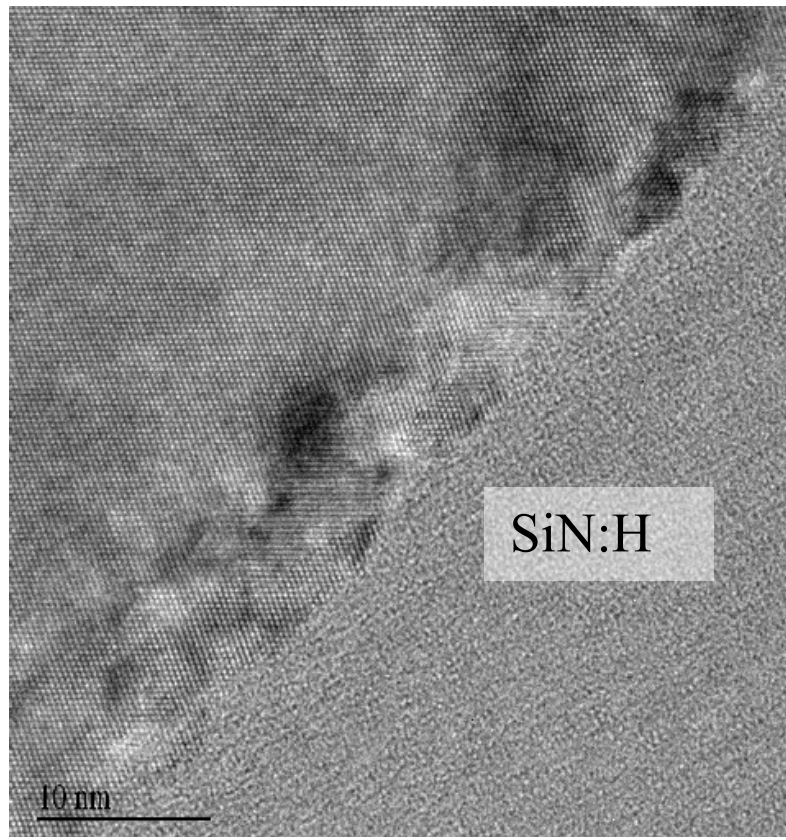

Figure 1. A [011] cross-sectional TEM lattice image of a Si ribbon deposited with a commercial $\mathrm{SiN}: \mathrm{H}$ (before alloying step) showing surface damage.

Figure 2 shows a SIMS plot of $\mathrm{H}$ (dotted line) in an EFG sample that was deposited with $\mathrm{SiN}: \mathrm{H}$ coating (before firing). The nitride was removed before SIMS analysis; we have confirmed that the nitride removal process did not alter the original $\mathrm{H}$ profile. Figure 2 shows existence of $\mathrm{H}$ near the surface and that the surface concentration reaches about $10^{22} \mathrm{~cm}^{-3}$. The depth of detectable $\mathrm{H}$ is about the same as that of the detectable damage in Fig. 1. This clearly shows association of $\mathrm{H}$ with PITs. The solid line in Figure 2 shows $\mathrm{H}$ profile of a similar sample after firing. It can be seen that $\mathrm{H}$ has diffused into the bulk of Si. However, there is still a high concentration of residual $\mathrm{H}$ near the surface. Analyses of many other samples have shown that there are significant variations in the $\mathrm{H}$ profile from sample to sample. Variations also exist within each sample, particularly after firing. This suggests that firing process may not "heal" surface damage uniformly over the sample. This inference is also corroborated by TEM analyses. The majority of each sample has very little residual damage after firing. However, we have found regions of samples that have extended defects, which look very similar to plasma hydrogenation but on a much smaller scale. Figure 3 shows a cross-sectional TEM of such a region in a fired sample. The defects below the nitride layer consist of platelets and "bubbles," as identified in the image.
Thus, some of the damage in the form of point-defect clusters has developed into extended defects by the firing.

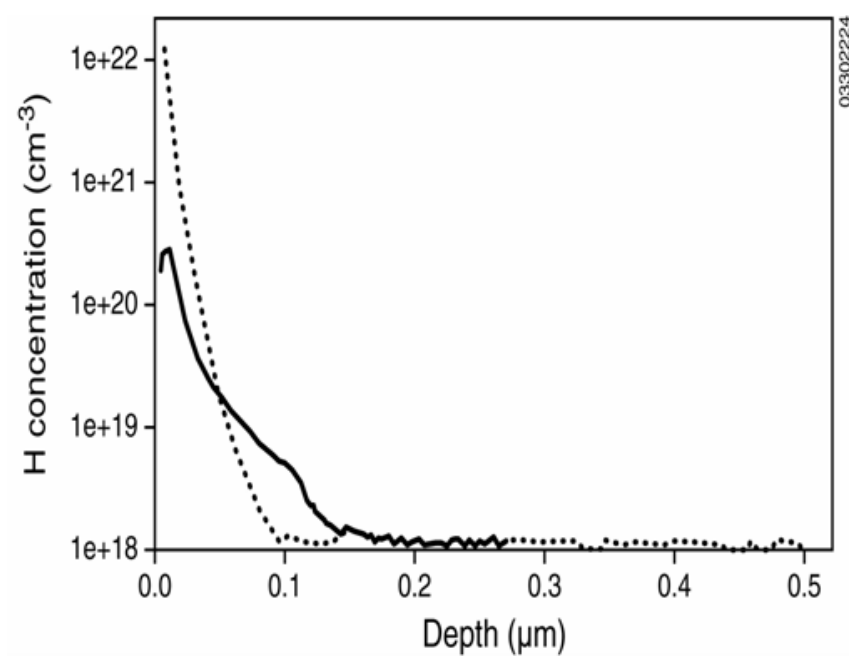

Figure 2. SIMS profiles of $\mathrm{H}$ before (dotted) and after firing (solid) the nitride-coated wafer. Nitride was removed prior to SIMS measurement.

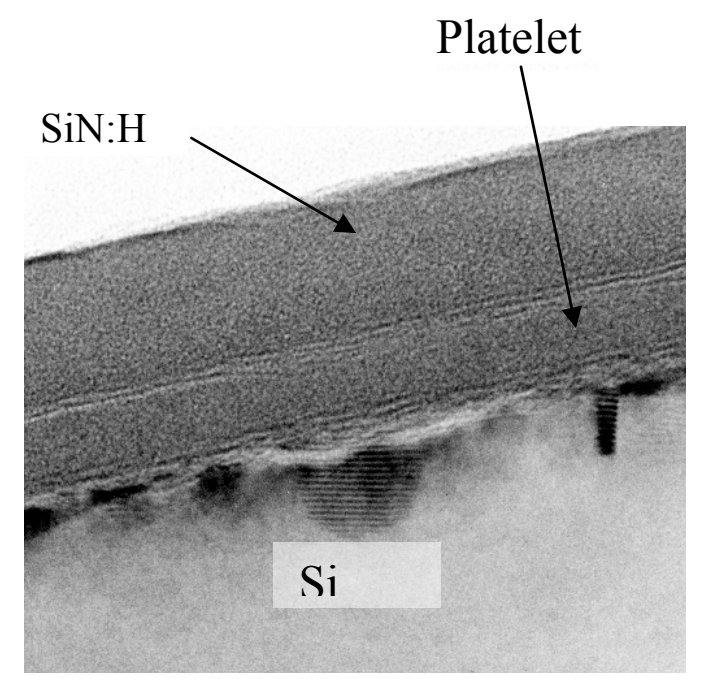

Figure 3. An X-TEM image of a fired, nitride-coated wafer showing a variety of extended defects generated by the firing process step.

\section{CONCLUSION}

We have verified that surface damage is produced in a PECVD process used for $\mathrm{SiN}: \mathrm{H}$ deposition. The damage (manifested as process-induced traps) "stores" $\mathrm{H}$, which is then driven into the bulk of $\mathrm{Si}$ during contact firing. During the cool-down of the firing process, the released $\mathrm{H}$, with a nearly uniform distribution in the bulk of the material will face competing mechanisms for its 
association. A part of the $\mathrm{H}$ will interact with the lifetime killing impurities - the most important from a passivation stand point-and with other impurities like dopants and intrinsic traps. It is necessary to ensure: (i) sufficient $\mathrm{H}$ available at the surface to passivate nearly all lifetime killing impurities, (ii) that $\mathrm{H}$ does not associate with dopants to change the resistivity of the material, and (iii) the surface damage is removed as much as possible. These considerations need attention to factors such as the nitride deposition method and pretreatment, firing conditions, and cool-down, for effective passivation. Some of these issues have already been reported in the literature. In particular, two important reported observations are: (a) low-frequency plasma nitride provides a better passivation than high-frequency plasma, and (b) slow cool-down results in higher cell efficiencies.

The role of the damaged layer is actually more complex than appears from the brief explanation offered in this paper. For example, the unhealed damaged layer can also mediate $\mathrm{H}$ between the $\mathrm{Si}$ and the $\mathrm{SiN}: \mathrm{H}$ layer. Furthermore, other process-induced traps such as dopants used for an N/P junction can influence the $\mathrm{H}$ transfer process. Some of this evidence has been observed experimentally. For example, PECVD passivation is better in wafer with N/P junction at the surface than in similar wafers where the $N$ region has been etched off, leaving only the p-type substrate [14]. The present model explains these results. Figures 4 and 5 show SIMS plots of $\mathrm{H}$, before and after firing, in two types p-type ribbon wafers - with and without an $n / p$ junction. These diffusion profiles exhibit features that can explain observed differences in the behavior of passivation in wafers with and without $n / p$ junctions.

\section{REFERENCES}

[1] P. Sana, A. Rohatgi, J. Kalejs and R. O. Bell, Appl. Phys. Lett. 64, 1994, p 111.

[2] J. Nijs et al., Proc. of the $1^{\text {st }}$ World Conference on Photovoltaic Energy Conversion, Hawaii, 1994, p 1242.

[3] V. Yelundur, A. Rohatgi, J-W. Jeong, A. M. Gabor, J.I. Hanoka, and R.L.Wallace, Procd. IEEE PVSC, 2000, p9.

[4] C. Boehme and G. Lucovsky, J. Appl. Phys., 88, 2000 p 6055.

[5] Z. Lu, P. Santos-Filho, G. Stevens, M.J. Williams, and G. Lucovsky, J. Vac. Sci. Technol. A 13(3), 1995, p 606.

[6] B.L. Sopori, Y. Zhang, R. Reedy, K. M. Jones, Y. Yan, M. M. Al-Jassim, J. Kalejs, and B. Bathey, On the Mechanism of Hydrogen Diffusion in Si Solar Cells Using PECVD SiN:H, MRS Spring 2004

[7] Bhushan Sopori, "Silicon Nitride Processing for Control of Optical and Electronic Properties of Silicon Solar Cells," J. Electronic Mat., 32, 2003, p 1034.
[8] J. P. Kalejs and S. Rajendran, App. Phys. Lett. 55, 1989, p 25.

[9] M. Capizzi and A. Mittiga, Appl. Phys. Lett. 50, 1987, p 918.

[10] A. Van Wieringen and N. Warmholtz, Physica 22, 1956, p 849.

[11] B. L. Sopori, Kim Jones and Xiao Jun Deng, Appl. Phys. Lett. 61, 1992, p 2560.

[12] N.M Johnson and C. Herring, Inst. Phys. Conf. Ser. 95, 1989, p 415.

[13] Bhushan Sopori, Y. Zhang, R. Reedy, K. Jones, N. M. Ravindra, S. Rangan, and S.Ashok, "Trapping and Detrapping of $\mathrm{H}$ in Si: Impact on Diffusion Properties and Solar Cell Processing, Proc. MRS Meeting, 719, 2002, pp 125-133.

[14] L. Mittelstadt, A. Metz, and R. Hezel, Solar Energy Materials \& Solar Cells, 72, 2002, pp 255-261.

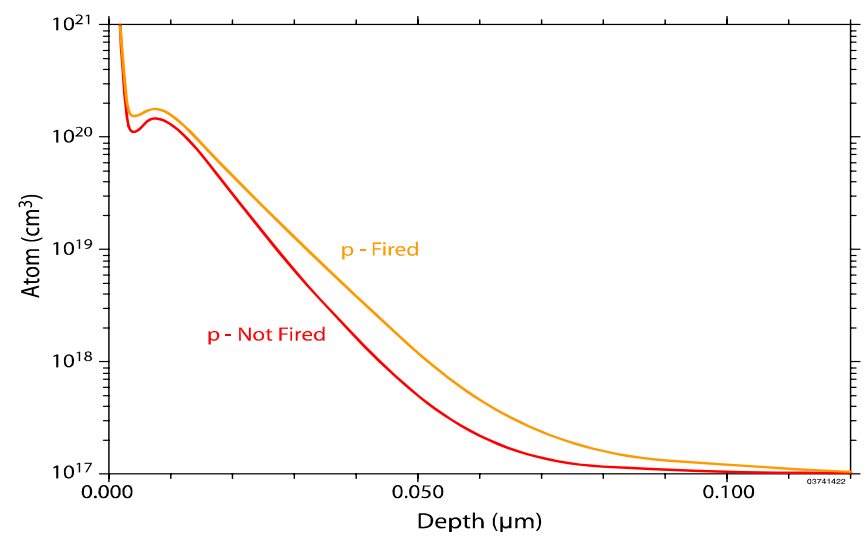

Figure 4. SIMS plots of $\mathrm{H}$ in p-type EFG ribbon before and after firing the nitride.

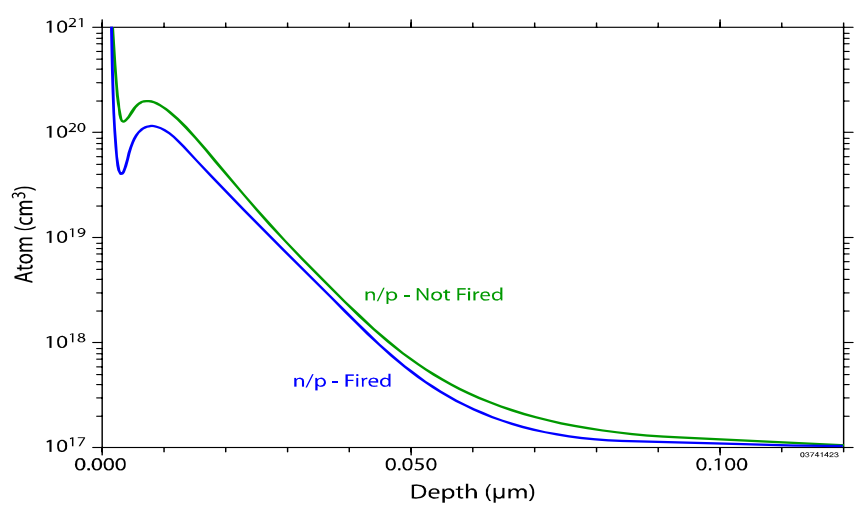

Figure 5. SIMS plots of $\mathrm{H}$ in $\mathrm{n} / \mathrm{p}$ EFG ribbon before and after firing the nitride. 


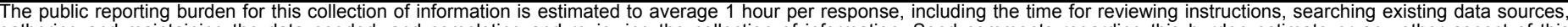

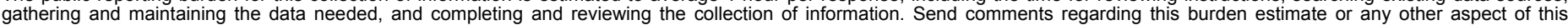

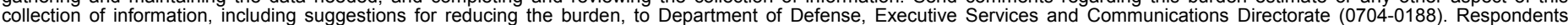

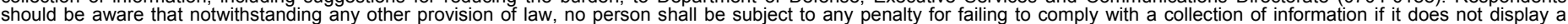

should be aware that notwithstanding

PLEASE DO NOT RETURN YOUR FORM TO THE ABOVE ORGANIZATION.

\begin{tabular}{l|l|l} 
1. $\begin{array}{l}\text { REPORT DATE }(D D-M M-Y Y Y Y) \\
\text { February } 2005\end{array}$ & 2. $\begin{array}{l}\text { REPORT TYPE } \\
\text { Conference Paper }\end{array}$ & $\begin{array}{l}\text { DATES COVERED (From - To) } \\
3-7 \text { January } 2005\end{array}$ \\
\hline
\end{tabular}

4. TITLE AND SUBTITLE

A Comprehensive Model of Hydrogen Transport into a Solar Cell

During Silicon Nitride Processing for Fire-Through Metallization 5a. CONTRACT NUMBER

DE-AC36-99-G010337

5b. GRANT NUMBER

5c. PROGRAM ELEMENT NUMBER

5d. PROJECT NUMBER

NREL/CP-520-37477

5e. TASK NUMBER

PVA53101

5f. WORK UNIT NUMBER

7. PERFORMING ORGANIZATION NAME(S) AND ADDRESS(ES)

National Renewable Energy Laboratory, 1617 Cole Blvd., Golden, CO

80401

Bioarray Solutions, Warren, NJ 07059

RWE Schott Solar, Billerica, MA 01821

8. PERFORMING ORGANIZATION REPORT NUMBER

NREL/CP-520-37477

9. SPONSORING/MONITORING AGENCY NAME(S) AND ADDRESS(ES)

10. SPONSOR/MONITOR'S ACRONYM(S) NREL

11. SPONSORING/MONITORING AGENCY REPORT NUMBER

12. DISTRIBUTION AVAILABILITY STATEMENT

National Technical Information Service

U.S. Department of Commerce

5285 Port Royal Road

Springfield, VA 22161

13. SUPPLEMENTARY NOTES

\section{ABSTRACT (Maximum 200 Words)}

A mechanism for the transport of $\mathrm{H}$ into a Si solar cell during plasma-enhanced chemical vapor deposition (PECVD) of a hydrogenated silicon nitride ( $\mathrm{SiN}: \mathrm{H})$ layer and its subsequent fire-through metallization process is described. The PECVD process generates process-induced traps, which "store" $\mathrm{H}$ at the surface of the solar cell. This stored $\mathrm{H}$ is released and diffuses rapidly into the bulk of Si during the high-temperature metallization-firing process. During the ramp-down, the diffused $\mathrm{H}$ associates with impurities and defects and passivates them. The firing step partially heals up the surface damage. The proposed model explains a variety of observations and experimental results.

15. SUBJECT TERMS

PV; hydrogen transport; solar cell; plasma-enhanced chemical vapor deposition (PECVD); hydrogenated silicon nitride (SiN:H); fire-through metallization;

\begin{tabular}{l|l|l|}
\hline 16. SECURITY CLASSIFICATION OF: \\
\hline \begin{tabular}{l|l} 
a. REPORT \\
Unclassified
\end{tabular} & $\begin{array}{l}\text { b. ABSTRACT } \\
\text { Unclassified }\end{array}$ & $\begin{array}{l}\text { c. THIS PAGE } \\
\text { Unclassified }\end{array}$ \\
\hline
\end{tabular}

\begin{tabular}{l|l} 
17. LIMITATION \\
OF ABSTRACT \\
UL
\end{tabular}

19a. NAME OF RESPONSIBLE PERSON
19b. TELEPHONE NUMBER (Include area code)

